\title{
Purification and Characterization of Peach Mosaic Virus
}

Carmen Gispert and Thomas M. Perring, Department of Entomology, and Rebecca Creamer, Department of Plant Pathology, University of California, Riverside 92521

\begin{abstract}
Gispert, C., Perring, T. M., and Creamer, R. 1998. Purification and characterization of peach mosaic virus. Plant Dis. 82:905-908.

Virus particles were observed by transmission electron microscopy in preparations extracted from symptomatic leaves of Chenopodium amaranticolor that had been mechanically inoculated with peach mosaic virus. The particles were long, flexuous, filamentous rods with an average length of $888 \mathrm{~nm}$. Purified preparations had an A 260/280 nm ratio of 1.25. RNA extracted from purified virus was approximately 8.1 kilobases, and a capsid protein of approximately $27 \mathrm{kDa}$ was found. Polyclonal rabbit antiserum, produced against purified virus, reacted with samples from peach mosaic and cherry mottle leaf-infected plants when used in Western blot analysis.
\end{abstract}

Peach mosaic virus (PMV) and cherry mottle leaf virus (CMLV) are graft-transmissible pathogens that naturally infect certain wild Prunus spp. These viruses are transmitted by distinct, but closely related, species of eriophyid mites that inhabit buds of different native plant species (21). Creamer et al. (6) detected PMV by enzyme-linked immunosorbent assay (ELISA) and Western blot tests using monoclonal antibodies developed against CMLV, suggesting the two viruses are serologically related.

PMV is transmitted naturally to peach (P. persica (L.) Batsch) and wild Prunus spp. by Eriophyes insidiosus Keifer and Wilson (20). Experiments suggest that PMV is transmitted to peach in a semipersistent manner (C. Gispert, unpublished). Peach trees infected with PMV present an assortment of symptoms throughout the year; these symptoms vary between seasons and between varieties of peach (25). Diseased trees show mosaic symptoms on the leaves, mottling and deformity of leaves and fruits, retardation of foliage development, and abnormal twig growth (23). Peach mosaic has been reported infecting peaches in much of the western United States and Arkansas (20) and in Mexico (22).

Cherry mottle leaf occurs naturally in sweet cherry (P. avium (L.)), ornamental flowering cherry ( $P$. serrulata Lindl.), peach, and apricot (P. armeniaca L.; 4). CMLV is transmitted by $E$. inaequalis Wilson \& Oldfield to wild bitter cherry $(P$. emarginata (Douglas); 20). The vector

Corresponding author: Carmen Gispert

E-mail: gispert@ucrac1.ucr.edu

Accepted for publication 29 April 1998.

Publication no. D-1998-0611-02R

(C) 1998 The American Phytopathological Society occurs on wild bitter cherry and is not known to reproduce on sweet cherry, apricot, or peach, even though it is able to transmit CMLV to peach and sweet cherry in the laboratory (G. N. Oldfield, unpublished). Characteristic symptoms caused by CMLV consist of chlorotic mottling, distortion, puckering, tattering, shot holes, Symptom severity varies between virus strains and between cultivars of the host involved. On some varieties, CMLV reduces fruiting, while on others it reduces fruit size and delays ripening (4).

This study presents the purification and physiochemical characterization of PMV.

\section{MATERIAL AND METHODS}

Virus-source. Twenty-five 1-year-old, healthy "Rio Oso Gem" (ROG) peach trees were grafted with budwood patches from ROG trees infected with a peach mosaic virus isolate collected from Chino, California. Infection of source and inoculated trees with PMV was confirmed by Western blot analysis using monoclonal antibodies to CMLV (6). These infected seedlings were maintained in the greenhouse at $27^{\circ} \mathrm{C}$.

Mechanical inoculation to an herbaceous plant. PMV was mechanically inoculated to Chenopodium amaranticolor Coste and Reyn. by grinding $1 \mathrm{~g}$ of symptomatic peach leaves in $10 \mathrm{ml}$ of $0.05 \mathrm{M}$ Tris and $0.01 \mathrm{M} \mathrm{MgSO}_{4}$ (TM buffer), containing $0.02 \mathrm{M}$ diethyldithiocarbamic acid (DIECA) and 0.04 M sodium thioglycolate (ST), final $\mathrm{pH} 9.5$, and $2.5 \%$ nicotine (11). For subsequent inoculations from Chenopodium to Chenopodium, TM buffer with DIECA and ST was prepared without nicotine. Plants were kept in the dark for $24 \mathrm{~h}$ prior to inoculation, and were inoculated approximately 3 weeks after germination by gently rubbing buffered sap extract onto leaves dusted with 600-mesh carborundum. Infected $C$. amaranticolor and a reduction in the size of the foliage. were maintained in the greenhouse for 1 month.

Virus purification. Various purification procedures were tested, including buffer solutions reported for purification of apple chlorotic leaf spot virus, beet yellows virus, and citrus tristeza virus. The buffers used were as follows: (i) $0.01 \mathrm{M}$ Tris, 0.5 $\mathrm{M}$ sodium sulfite, $2 \%$ mercaptoethanol, 10 $\mathrm{mg} / \mathrm{g}$ fresh weight bentonite, $\mathrm{pH}$ 9.0; (ii) $0.01 \mathrm{M}$ ammonium acetate, $\mathrm{pH} 8.0,0.02 \mathrm{M}$ EDTA, 0.02 DIECA (12); (iii) $0.01 \mathrm{M}$ Tris, $\mathrm{pH}$ 9.0, $0.01 \mathrm{M}$ magnesium chloride, 0.001 M spermidine, $10 \mathrm{mg} / \mathrm{g}$ fresh weight bentonite (8); and (iv) $0.1 \mathrm{M}$ sodium citrate, $\mathrm{pH}$ 6.0, 2\% Driselase, 10\% sucrose, $0.5 \%$ mercaptoethanol, $1 \mathrm{mM}$ phenylmethylsulfonyl fluoride (15).

Symptomatic peach leaf tissue was powdered in liquid nitrogen, homogenized in three volumes of buffer, filtered through cheesecloth, and the supernatant was centrifuged at 3,000 rpm for $5 \mathrm{~min}$ in a Sorvall GSA rotor. To concentrate and clarify the supernatant, polyethylene glycol 6000 was added at a rate of $8 \mathrm{~g} / 100 \mathrm{ml}$ and $\mathrm{NaCl}$ was added to a final concentration of $0.1 \mathrm{M}$. Triton $\mathrm{X}-100$ was added to $25 \%(\mathrm{vol} / \mathrm{vol})$. The supernatant solution was stirred for $1 \mathrm{~h}$ at $4^{\circ} \mathrm{C}$, then the mixture was centrifuged at $9,000 \mathrm{rpm}$ in a Sorvall GSA rotor for 20 min. The pellets were resuspended in onetenth volume extraction buffer and layered onto linear sucrose gradients composed of $3 \mathrm{ml}$ each of 10 to $40 \%$ sucrose ( $\mathrm{vol} / \mathrm{vol})$ in extraction buffer. Gradients were centrifuged at 40,000 rpm for $2 \mathrm{~h}$ in an SW 41 rotor and fractionated with an ISCO model 640 fractionator equipped with a model UA-5 analyzer. Virus from the fractions was concentrated by centrifugation at $40,000 \mathrm{rpm}$ for $1.5 \mathrm{~h}$ in a 50.2 Ti rotor and the pellets resuspended in $0.01 \mathrm{M}$ Tris, $0.01 \mathrm{M} \mathrm{MgCl}_{2}, \mathrm{pH}$ 7.0. The viral antigen was monitored during the various purification steps by Western blot analysis using monoclonal antibody to CMLV (provided by D. James, Sidney, British Columbia), which reacted positively to PMV.

The method of James and Mukerji (11) for extraction of CMLV was used with minor modifications to obtain purified preparations of PMV from C. amaranticolor leaves. Infected leaves, harvested approximately 21 to 28 days after inoculation, were powdered in liquid nitrogen, homogenized in 3 volumes of buffer $(0.05$ M Tris, $0.01 \mathrm{M} \mathrm{MgSO}_{4}, \mathrm{pH} 8.5$, containing $0.02 \mathrm{M}$ mercaptoethanol), and squeezed through four layers of cheese cloth. Activated charcoal $(4.5 \mathrm{~g} / 100 \mathrm{ml}$ of homogen- 
ate) was added, and the mixture was stirred for $10 \mathrm{~min}$ in an ice bath and centrifuged at $7,000 \mathrm{~g}$ for $15 \mathrm{~min}$ in a GSA rotor. A preparation of Mg-bentonite (9) was added to $70 \mathrm{mg} / 100 \mathrm{ml}$ of supernatant, and the mixture was stirred in an ice bath for 10 min, incubated at $4^{\circ} \mathrm{C}$ for $20 \mathrm{~min}$, and centrifuged at 7,000 $\mathrm{g}$ for $15 \mathrm{~min}$ in a GSA rotor. The supernatant was adjusted to $6 \%$ polyethylene glycol (wt/vol) and $0.02 \mathrm{M}$ $\mathrm{NaCl}$. The mixture was stirred on ice for 1 $\mathrm{h}$, incubated at $4^{\circ} \mathrm{C}$ for $1 \mathrm{~h}$, and centrifuged at $14,500 \mathrm{~g}$ for $20 \mathrm{~min}$ in a GSA rotor. The pellet was resuspended in $20 \mathrm{ml}$ of TM buffer and centrifuged at 7,000 $\mathrm{g}$ for 15 min in a Sorvall SS-34 rotor. The supernatant was centrifuged at $145,510 \mathrm{~g}$ for $1.45 \mathrm{~h}$ in a $50.2 \mathrm{Ti}$ rotor. The resulting pellet was resuspended in $200 \mu \mathrm{l}$ of TM buffer and stirred slowly overnight at $4{ }^{\circ} \mathrm{C}$. The resuspended pellet was microcentrifuged at 15,000 rpm for $5 \mathrm{~min}$. The supernatant was observed by transmission electron microscopy to verify the presence of virus particles. As a control, tissue from healthy $C$. amaranticolor was subjected to the same purification method described above.

Electron microscopy. Purified virion preparations were either placed directly or diluted 10-fold and placed on Formvar heavily coated carbon grids stained with $2 \%$ uranyl acetate and examined with a Hitachi H-600 transmission electron microscope. The average particle size was calculated from measurements of 20 particles from purified preparations. Calibra- tions were made using a grid replica (Ernest F. Fullam, Inc., Latham, NY).

Analysis of PMV RNA. Nucleic acids were extracted from freshly purified virions resuspended in $200 \mu \mathrm{l}$ TM buffer. An equal volume of phenol was added and the aqueous phase was re-extracted with phenol prior to ethanol precipitation. The RNA pellet was dried and resuspended in distilled water. The RNA sample was denatured with glyoxal (24) and electrophoresed on a $1.0 \%$ agarose gel in $10 \mathrm{mM}$ sodium phosphate buffer ( $\mathrm{pH} 7.0$ ) for $3 \mathrm{~h}$ at $60 \mathrm{~V}$. The nucleic acid size was estimated by comparing its migration with RNA standards (Gibco-BRL, Gaithersburg, $\mathrm{MD})$.

The dsRNA was extracted as described by Creamer and Falk (5). After ethanol precipitation, the pellet was resuspended in $200 \mu \mathrm{l}$ sterile water and $1 \mu \mathrm{l}$ DNAse (RQ1; Promega Corp., Madison, WI), and $0.5 \mu \mathrm{l} 2$ $\mathrm{M} \mathrm{MgCl}{ }_{2}$ were added. Electrophoresis of dsRNA was done in a $6 \%$ polyacrylamide gel at $100 \mathrm{~V}$ for $3 \mathrm{~h}$ at room temperature. The gel was stained with ethidium bromide ( $1 \mathrm{mg} / \mathrm{ml}$ ). The sizes were estimated by comparison with the dsRNA of citrus tristeza closterovirus, tobacco etch potyvirus, and cucumber mosaic cucumovirus. Alternatively, the dsRNA was denatured and electrophoresed as was done for virion RNA and the denatured sizes were estimated as compared to migration with denatured RNA standards (Gibco-BRL).

Serological analysis. Antiserum against PMV was produced by mixing equal vol-

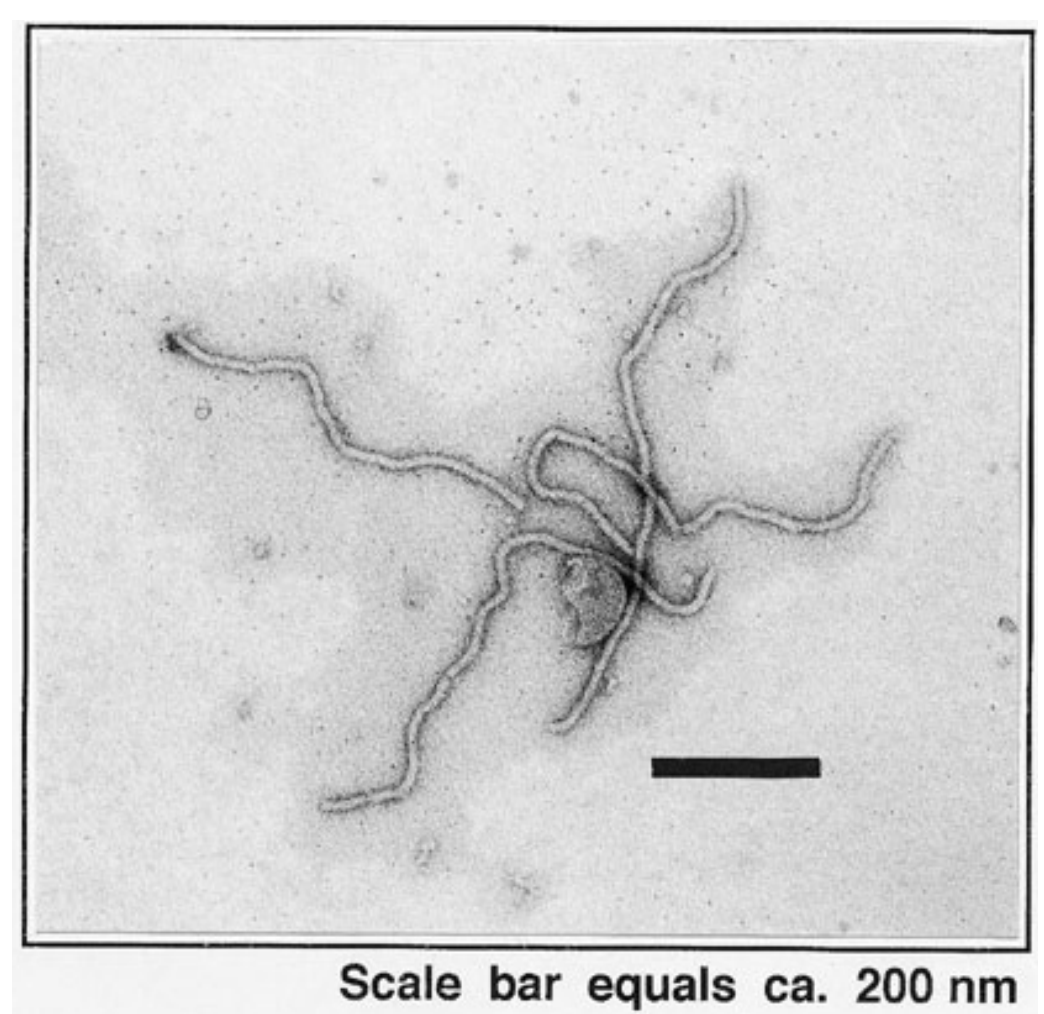

Fig. 1. Electron micrograph of purified, virus-like, uranyl acetate-stained particles extracted from Chenopodium amaranticolor infected with peach mosaic virus. Scale bar $=$ approximately $200 \mathrm{~nm}$. umes of purified virions with Freund's adjuvant and injecting a rabbit subcutaneously with emulsion containing $800 \mu \mathrm{l}$ of approximately $0.34 \mu \mathrm{g} / \mathrm{ml}$ of antigen. Four injections were made at 14-day intervals with Freund's complete adjuvant added in the first injection and incomplete adjuvant in subsequent injections. Bleedings began 14 days after the final injection and continued at 14-day intervals for 4 weeks. Immunoglobulin $\mathrm{G}$ ( $\mathrm{IgG}$ ) was purified using a protein-A Sepharose column (24).

For detection of the coat protein, samples were prepared by grinding $0.25 \mathrm{~g}$ of infected tissue in liquid nitrogen and adding $1.5 \mathrm{ml}$ of Laemmli buffer (14). Samples were mixed, boiled for $5 \mathrm{~min}$, microcentrifuged at 15,000 rpm for $3 \mathrm{~min}$, and the supernatant was decanted to a new tube. Proteins were analyzed by electrophoresis in a $15 \%$ polyacrylamide gel containing sodium-dodecyl-sulfate (SDSPAGE). The molecular mass of virion proteins was estimated by comparing their relative mobility with molecular mass standards (Bio-Rad Laboratories, Richmond, CA). SDS-PAGE gels were transferred to Immobilon-P membrane (Millipore Corp., Bedford, MA), and membranes were blocked with 5\% nonfat dry milk for $1 \mathrm{~h}$. PMV or CMLV IgGs and alkaline phosphatase-conjugated goat anti-rabbit IgG (heavy and light) were used at 1:2,000 dilution. PMV antiserum was cross-

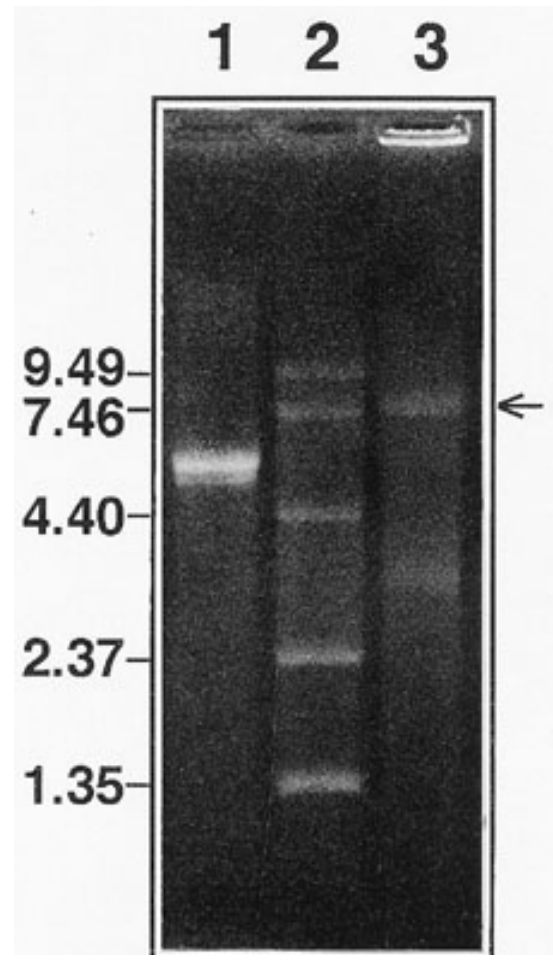

Fig. 2. A 1\% agarose gel showing virion RNA (indicated by arrow) after denaturation with glyoxal and DMSO, electrophoresis, and staining with ethidium bromide. Lane 1, tobacco mosaic tobamovirus; lane 2, RNA molecular mass standards in kilobases; lane 3, peach mosaic virus. 
absorbed by mixing with peach sap from healthy trees (prepared by grinding $5 \mathrm{~g}$ peach leaves in $20 \mathrm{ml}$ of buffer containing $10 \mathrm{mM}$ Tris, $150 \mathrm{mM} \mathrm{NaCl}, 0.05 \%$ Tween, $\mathrm{pH} 8$, centrifuging briefly, and using the supernatant) and incubating for $1 \mathrm{~h}$ at $37^{\circ} \mathrm{C}$. Nitrobluetetrazolium (NBT) and 5bromo-4chloro-3-indoyl-B-D-galactoside (BCIP) were added for color development.

\section{RESULTS}

Mechanical inoculation to a herbaceous plant. Using the buffer suggested by James and Mukerji (11), inoculation of PMV to $C$. amaranticolor was successful. C. amaranticolor inoculated with PMV from infected peach showed chlorotic spots on the leaves 15 to 20 days post-inoculation. After inoculation of PMV onto $C$. amaranticolor for several generations, symptoms on infected plants were more pronounced. Approximately 4 weeks postinoculation, chlorotic spots progressed into chlorotic patches and infected plants showed pronounced vein clearing. Some of the plants also showed enations and wrinkling of the leaves.

Virus purification and electron microscopy. Purification of PMV from peach leaves was partially successful. When viral antigen was monitored with monoclonal antibodies to CMLV, buffers containing Tris showed the highest levels of viral antigen. The use of EDTA was necessary to prevent aggregation of viral particles with ribosomes. Although final preparations from peach extractions contained

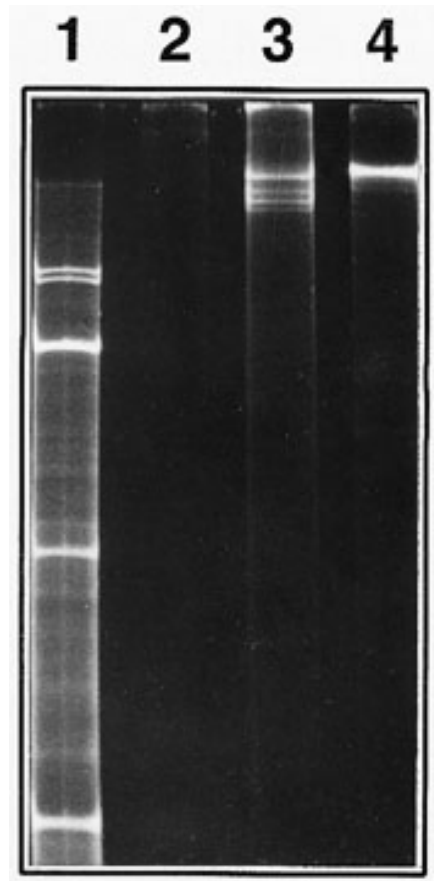

Fig. 3. Electrophoresis of dsRNAs through a $6 \%$ polyacrylamide gel, followed by ethidium bromide staining. Lane 1, tobacco etch potyvirus and cucumber mosaic cucumovirus; lane 2, healthy Chenopodium amaranticolor; lane 3, PMV-infected $C$. amaranticolor; lane 4, citrus tristeza closterovirus. excessive plant material, long, flexuous, rod-like virus particles were observed by electron microscopy when buffer containing $0.01 \mathrm{M}$ Tris, $0.01 \mathrm{M} \mathrm{MgCl}_{2}, 0.001 \mathrm{M}$ spermidine phosphate, $0.02 \mathrm{M}$ EDTA, $\mathrm{pH}$ 9.0, was used.

All preparations extracted from infected C. amaranticolor showed long, flexuous, rod-shaped virus particles of various lengths in electron microscopy (Fig. 1). The average $(n=20)$ particle length was $888 \mathrm{~nm}$. Purified preparations also showed small, spherical particles about $13.6 \mathrm{~nm}$ in diameter which were thought to be ribosomes. These were reduced dramatically when the final preparation was centrifuged for $5 \mathrm{~min}$ at $15,000 \mathrm{rpm}$. The average A $260 / 280 \mathrm{~nm}$ value for the purified preparation was 1.25 . The virus was spectrophotometrically quantified using an extinction coefficient of $2(\mathrm{mg} / \mathrm{ml})^{-1} \mathrm{~cm}$ at $260 \mathrm{~nm}$ derived from beet yellows virus (1). An average virus yield of $0.07 \mu \mathrm{g} / 100 \mathrm{~g}$ of leaf tissue was estimated.

Analysis of PMV RNA. Electrophoresis of nucleic acid denatured with glyoxal in a $1 \%$ agarose gel revealed a band of approximately 8.1 kilobases (kb; Fig. 2). Electrophoresis of dsRNA showed four bands of approximately 7.1, 5.8, 5.1, and $4.1 \times 10^{6} \mathrm{~kb}$ (Fig. 3). Electrophoresis of the denatured dsRNAs revealed only the three largest RNAs (data not shown).

Serological analysis. Antiserum produced against PMV reacted positively with purified virions and infected plants. In Western blot analysis, using antibodies made against PMV, a band of approximately $27 \mathrm{kDa}$ was detected in purified virion preparations, crude extracts of infected $C$. amaranticolor, and in both symptomatic and asymptomatic peach leaves (Fig. 4). A band at approximately 53 $\mathrm{kDa}$ was detected in extracts of both infected and healthy peaches and $C$. ama- ranticolor and is likely a nonspecific background reaction with plants.

\section{DISCUSSION}

The difficulty of purification of peach mosaic virus from peach is thought to be due to the relatively low concentration of the virus and the presence of large amounts of mucilage, a heteropolysaccharide which is known to cause serious difficulties in the isolation and preservation of viruses (26). In addition to this, proteins, polysaccharides, and the presence of phenolic substances such as tannins may inhibit virus infection when using inoculum prepared from peach tissue (18).

The presence of sodium thioglycolate, nicotine, magnesium, and a high $\mathrm{pH}$ in the buffer all probably contributed to the success of the mechanical inoculation of PMV to $C$. amaranticolor. The high-pH buffer (8) and the divalent cation magnesium (16) have been shown to promote stability of some closterovirus-like particles. Sodium thioglycolate is a reducing agent that can inhibit the action of phenolics and nicotine reduces the precipitation and inactivation of viruses by tannins.

The virions obtained from purified preparations were $888 \mathrm{~nm}$ in length with a coat protein of approximately $27 \mathrm{kDa}$ and a 8.1-kb RNA. The size of the coat protein and RNA of PMV are in the same range as those reported for CMLV, $20.5 \mathrm{kDa}$ and 8.2 $\mathrm{kb}$, respectively (11).

The physio-chemical characteristics which we determined for PMV show similarities with those of closteroviruses, capilloviruses, and trichoviruses. The particle length of $888 \mathrm{~nm}$ for PMV is shorter than the 1,200 to $2,200 \mathrm{~nm}$ reported for closteroviruses (2), but is somewhat longer than the $640 \mathrm{~nm}$ reported for capilloviruses (19) and the 640 to $800 \mathrm{~nm}$ reported for trichoviruses (3). The capsid protein size of

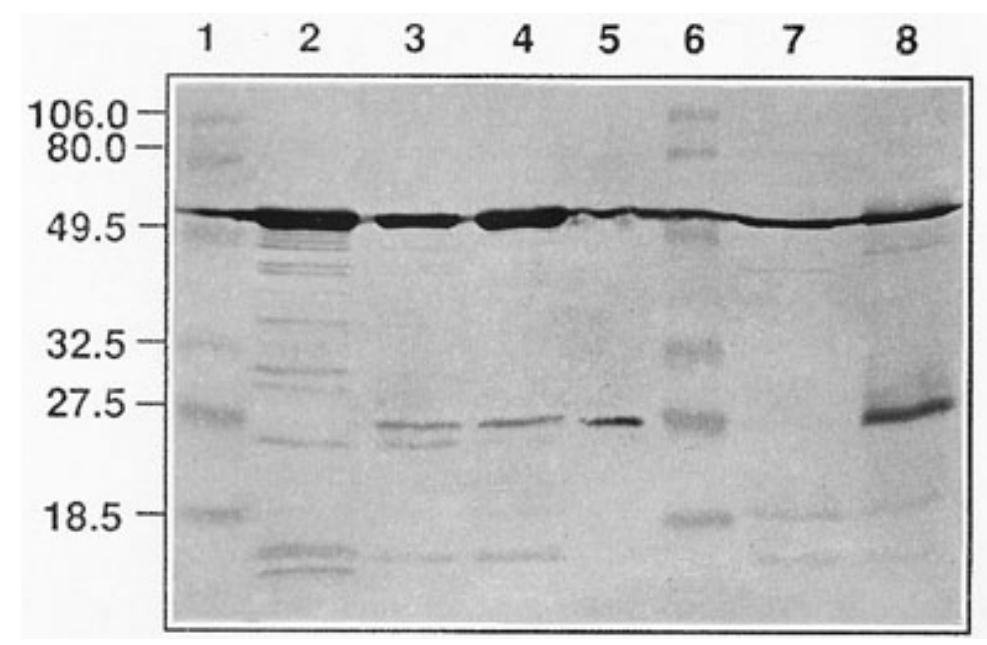

Fig. 4. Western blot analysis of peach mosaic virus (PMV) proteins. Denatured proteins were electrophoresed through a $15 \%$ sodium dodecyl sulfate-polyacrylamide gel electrophoresis, followed by electro-blotting to polyvinylidene difluoride membranes and treatment with PMV immunoglobulin G. Lane 1, protein markers; lane 2, healthy peach; lane 3, infected peach leaf; lane 4, infected peach leaf without symptoms; lane 5, purified PMV; lane 6, protein markers; lane 7, healthy peach bud; lane 8 , infected peach bud. Molecular mass size standards are indicated in $\mathrm{kDa}$. 
$27 \mathrm{kDa}$ for PMV is similar to the 23 to 28 $\mathrm{kDa}$ reported for closteroviruses (2), 27 $\mathrm{kDa}$ for capilloviruses (19), and 22 to 27 $\mathrm{kDa}$ for trichoviruses (3). The size of the PMV genomic RNA $(8.1 \mathrm{~kb})$ is similar to that reported for lettuce infectious yellows closterovirus (13), larger than the $6.5 \mathrm{~kb}$ reported for capilloviruses (19), but similar to the 7.5 to 8.7 reported for trichoviruses (17). The multiple high molecular mass dsRNA bands found for PMV are not consistent with those found for closteroviruses (7); however, multiple high molecular mass dsRNA bands have been described for trichoviruses (10). We suggest that PMV appears to be most closely related to trichoviruses, in contrast to the report that CMLV is likely a closterovirus (11). However, characterization of the genome of PMV will be necessary before this virus can be definitively assigned to a virus group.

The purified virus was detected by Western blot using a polyclonal antibody to PMV and monoclonal antibody to CMLV. Similarities in the characteristics of the virions, and the fact that both antibodies react to either of the two viruses, suggests that these two viruses are closely related and might be strains of the same virus. However, given the differences in host ranges and vectors between these two viruses, we conclude that they are distinct viruses.

Peach mosaic symptoms are influenced greatly by environmental conditions, virus strain, and peach variety, which make visual detection difficult and uncertain. The availability of a serological method to detect PMV supports the establishment of an indexing program, the first step in designing a management strategy.

\section{ACKNOWLEDGMENTS}

We thank D. James for the gift of CMLV monoclonal antibody used for virus detection, and K. Harper for her help with electron microscopy.

\section{LITERATURE CITED}

1. Bar-Joseph, M., and Hull, R. 1974. Purification and partial characterization of sugar beet yellows virus. Virology 62:552-562.

2. Candresse, T., and Martelli, G. P. 1995. Genus Closterovirus. Pages 461-464 in: Virus Taxonomy. 6th Rep. Int. Committee Taxon. Viruses. F. A. Murphy, C. M. Fauquet, D. H. L. Bishop, S. A. Ghabrial, A. W. Jarvis, G. P. Martelli, M. A. Mayo, and M. D. Summers, eds. Springer-Verlag, New York.

3. Candresse, T., Namba, S., and Martelli, G. P. 1995. Genus Trichovirus. Pages 468-470 in: Virus Taxonomy. 6th Rep. Int. Committee Taxon. Viruses. F. A. Murphy, C. M. Fauquet, D. H. L. Bishop, S. A. Ghabrial, A. W. Jarvis, G. P. Martelli, M. A. Mayo, and M. D. Summers, eds. Springer-Verlag, New York.

4. Cheney, P. W., and Parish, C. L. 1976. Cherry mottle leaf. Pages 49-54 in: Virus diseases and noninfectious disorders of stone fruits in North America U. S. Dep. Agric. Handb. No. 437.

5. Creamer, R., and Falk, B. W. 1989. Characterization of a nonspecifically aphid-transmitted CA-RPV isolate of barley yellow dwarf virus. Phytopathology 79:942-946.

6. Creamer, R., Gispert, C., and Oldfield, G. N. 1994. Partial characterization of peach mosaic virus. Pages 21-23 in: Proceedings of the Rose Rosette Symposium. A. Epstein and J. Hill, eds. Iowa State University, Ames.

7. Dodds, J. A., and Bar-Joseph, M. 1983. Double-stranded RNA from plants infected with closteroviruses. Phytopathology 73:419-423.

8. Dunez, J., Delbos, R., and Bertranet, R. 1973. Le rôle de differents facteurs de stabilization appliqués à la purification du virus du chlorotic leaf spot du pommier (CLSV). Ann. Phytopathol. 5:255-264.

9. Dunn, D. B., and Hitchborn, J. H. 1965. The use of bentonite in the purification of plant viruses. Virology 25:171-192.

10. German, S., Candresse, T., Le Gall, O. Lanneau, M., and Dunez, J. 1992. Analysis of the dsRNAs of apple chlorotic leaf spot virus. J. Gen. Virol. 73:767-773.

11. James, D., and Mukerji, S. 1993. Mechanical transmission, identification, and characterization of a virus associated with mottle leaf in cherry. Plant Dis. 77:271-275.

12. Kassanis, B., Carpenter, J., White, R., and Woods, R. 1977. Purification and some properties of beet yellows virus. Virology 77:95-100.

13. Klaassen, V. A., Boeshore, M. L., Koonin, E. V., Tian, T., and Falk, B. W. 1995. Genome structure and phylogenetic analysis of lettuce infectious yellows virus, a whitefly-transmitted, bipartite closterovirus. Virology 208:99-110.

14. Laemmli, U. K. 1970. Cleavage of structural proteins during assembly of the head of bacteriophage T4. Nature 227:680-683.

15. Lee, R. F., Garnsey, S. M., Brlansky, R. H., and Goheen, A. 1987. A purification procedure for enhancement of citrus tristeza yields and it application to the phloem-limited viruses. Phytopathology 77:543-549.

16. Lister, R. M., and Hadidi, A. F. 1971. Some properties of apple chlorotic leafspot virus and their relation to purification problems. Virology 45:240-251.

17. Martelli, G. P., Candresse, T., and Namba, S. 1994. Trichovirus, a new genus of plant viruses. Arch. Virol. 134:451-455.

18. Matthews, R. E. F. 1991. Plant Virology. Third edition. Academic Press, San Diego.

19. Namba, S. 1995. Genus Capillovirus. Pages 465-467 in: Virus Taxonomy. 6th Rep. Int Committee Taxon. Viruses. F. A. Murphy, C. M. Fauquet, D. H. L. Bishop, S. A. Ghabrial, A. W. Jarvis, G. P. Martelli, M. A. Mayo, and M. D. Summers, eds. Springer-Verlag, New York.

20. Oldfield, G. N. 1970. Mite transmission of plant viruses. Annu. Rev. Entomol. 15:343380 .

21. Oldfield, G. N. 1994. Eriophyid mites as vectors of plant disease agents. Pages 11-16 in: Proceedings of the Rose Rosette Symposium. A. Epstein and J. Hill, eds. Iowa State University, Ames.

22. Oldfield, G. N., Creamer, R., Gispert, C., Osorio, F., Rodriguez, R., and Perring, T. M. 1995. Incidence and distribution of peach mosaic and its vector Eriophyes insidiosus (Acari: Eriophyidae) in Mexico. Plant Dis. 79:186-189.

23. Pine, T. S. 1976. Peach mosaic. Pages 61-72 in: Virus diseases and noninfectious disorders of stone fruits in North America U. S. Dep. Agric. Handb. No. 437.

24. Sambrook, J., Fritsch, E. F., and Maniatis, T. 1989. Molecular Cloning: A Laboratory Manual. Cold Spring Harbor Laboratory Press, Cold Spring Harbor, New York.

25. Stout, G. L. 1939. Peach Mosaic. Calif. Dep. Agric. Bull. 28:177-200.

26. Zagula, K. R., Aref, N. M., and Ramsdell, D. C. 1989. Purification, serology, and some properties of a mechanically transmissible virus associated with green ring mottle disease in peach and cherry. Phytopathology 79:451-456. 